\title{
New legitimacy to concerns about fracking and health
}

$\mathrm{W}$ hile scientists and area residents have been sounding the alarm about the health impacts of shale gas drilling for years, recent studies, a legal decision and public health advocates are bringing greater legitimacy to concerns.

Hydraulic fracturing, or fracking, involves drilling vertically, then horizontally, into shale rock to obtain methane or natural gas. Water, chemicals and sand are blasted into the drilled wells, creating cracks in the adjacent rock and releasing the gases into the well. The process requires dozens of chemicals for various purposes, including reducing heat and suspending drill cuttings to avoid clogs.

Fracking is booming in northeastern $\mathrm{BC}$, where more than 7300 shale gas wells have been drilled, as well as in Alberta and New Brunswick. The provinces of Quebec, Newfoundland and Labrador, and Nova Scotia have imposed moratoriums on fracking until more evidence about its effects on the environment and health is available.

But the epicentre of fracking is south of the border, in Pennyslvania, where officials have embraced the economic opportunity of the Marcellus shale deposit, one of the largest in the world. The industry's sway in that state led to 2012 gas-drilling legislation that featured a medical gag rule; physicians were permitted to investigate fracking chemicals, but barred from disclosing information to patients. Nephrologist Dr. Alfonso Rodriguez, who launched a First Amendment lawsuit challenging the law, was one of the physicians leading the fight against the gag order, which was overturned by Pennsylvania's Supreme Court in December 2013. He did not return calls from CMAJ.

leading what it calls a public health response to the shale gas industry. Staff document residents' symptoms and monitor pollutants in the air so they can warn residents about peaks. Dr. Leslie Walleigh, the medical and occupational health consultant with the project, says the most common symptoms that residents blame on fracking are respiratory, including coughing, shortness of breath and worsening asthma.

Despite the viral videos of flaming methane-laden tap water, some scientists are now saying air pollution associated with shale gas drilling may be a bigger threat than water contamination.

"When they punch a hole in the ground, you're going to get air pollution coming up," says Carol Kwiatkowski, executive director of the science-based nonprofit research organization The Endocrine Disruption Exchange in Paonia, Colorado.

In addition to releasing toxic gases, like benzene, that occur naturally in the rock, the chemicals that are added to the fracking water also come back up. Often, the chemicalcontaining gas is vented and the toxic waste water is stored in open pits; both processes release volatile organic compounds into the air, says Kwiatkowski, who is an assistant professor adjunct in the Department of Integrative Physiology at the University of Colorado, Boulder.

Kwiatkowski and colleagues collected weekly air samples for 12 months in

Hydraulic fracturing, or fracking, such as this operation west of Farmington, British Columbia, near Dawson Creek, uses toxic chemicals and releases toxic gases.

Interest groups have not been sitting idle waiting for this decision. Dissatisfied with the lack of information available for residents, the Southwest Pennsylvania Environment Health Project has been
Garfield County, Colo. within one mile of 130 shale gas wells. Their study, published this year in Human and Ecological Risk Assessment: an International Journal, reported 61 airborne chemicals. 
One of the most concerning was methylene chloride, which may be a carcinogen, according to the Environmental Protection Agency. Acute inhalation can be fatal, while chronic exposure can cause memory loss, nausea and respiratory symptoms. This highpowered cleaning solvent was detected in $73 \%$ of the weekly air samples, at times spiking above 563 parts per billion by volume (ppbv). There is no national standard for acceptable levels of airborne methylene chloride, but the Wisconsin Department of Natural Resources says action should be taken if indoor methylene chloride levels are above 15 ppbv.

Another set of chemicals causing concern are polycyclic aromatic hydrocarbons (PAHs). Kwiatkowski's study reported levels at 15.5 nanograms per cubic metre $\left(\mathrm{ng} / \mathrm{m}^{3}\right)$; previous studies by the Columbia Center for Children's Environmental Health correlated prenatal exposure levels of PAHs greater than $2.26 \mathrm{ng} / \mathrm{m}^{3}$ and $4.16 \mathrm{ng} / \mathrm{m}^{3}$ with lower IQ scores and delayed mental development.

Another study, published Jan. 28, 2014 in Environmental Health Perspectives, compared live-birth data over a 13-year period with geographic proximity to natural gas drilling and found that babies born to homes with more than 125 wells within a mile radius had a $30 \%$ greater prevalence of congenital heart defects than those with no wells within 10 miles. However, lead author Lisa McKenzie, a researcher at the Colorado School of Public Health, University of Colorado in Aurora, warns that the findings show only a "correlation."

\section{Water contamination}

While air pollution is being seen as inherent to the fracking process, water contamination can also occur because of unintended leaks or spills. In 2010, the Environmental Protection Agency sampled groundwater near EnCana shale gas sites in Wyoming and warned residents not to cook with or drink the water because of the presence of benzene, methane and other hydrocarbons.

"Some of the chemicals used are carcinogens," says Dr. Warren Bell, a Salmon Arm, British Columbia, family physician and founding member of the Canadian Association of Physicians for the Environment. "There are also things like methanol, which is a wood alcohol and something that if your kid accidentally drinks it, they could go blind and die."

At the Southwest Pennsylvania Environment Health Project, Walleigh reports four residents' water wells have tested positive for contaminants including benzene, toluene, arsenic, and metals such as manganese, barium and strontium.

Water contamination can also occur off-site due to the disposal of chemical-containing water. Mike Benusic, a medical student who published a review of the available literature on fracking with the Environmental Health Committee, Doctors of BC, says the waste water is stored in underground concrete reservoirs, but spills or improper disposal are highly possible, given the sheer volume of fracking waste fluid (4.2 billion litres in 2009 alone). "The water is often disposed 100 kilometres away," he says. "There are so many areas in that link where there's a possibility of a leak."

\section{Industry response}

David Pryce, vice president of operations of the Canadian Association of Petroleum Producers (CAPP) says the shale gas industry in Canada is taking steps to allay public health concerns. CAPP is funding a regional independent air monitoring system in $\mathrm{BC}$ and has lobbied government to mandate disclosure requirements for the chemicals used. Both BC and Alberta made disclosure mandatory in 2012.

Pryce also explained that, in Canada, there are about two kilometres of "very tight porosity rock" between water aquifers and shale gas wells. In the Wyoming case, by comparison, the aquifers were at times only 100 metres from the gas wells.

Although Pryce underlined that fracking has been done for decades without incident in Canada, Bell is not comforted by the industry's assurance. "This is a whole new process," he says, noting that only a decade ago fracking was done only on a very small scale, because the technology of horizontal drilling hadn't been developed.

Dr. Charl Badenhorst, medical health officer for the Northern Health Authority in $\mathrm{BC}$, is equally concerned by the rapid pace and dearth of independent impact assessments surrounding fracking. "There's limited information available from a science point of view," he says.

The BC and federal governments are only now conducting reviews into the environmental and health effects of fracking, due later this year. The Council of Canadian Academies' panel of geologists, toxicologists, public health experts and more will also be releasing a report in mid-May on the environmental impacts of fracking. The panel is assessing the available peer-reviewed literature, identifying gaps in knowledge and making mitigation recommendations, according to program director Douglas Wright.

Meanwhile, other implications are impossible to measure, says Bell. Despite industry assurances that less than $1 \%$ of methane gas leaks during the fracking process, independent analyses reported in Nature, have shown leakage to be high as $9 \%$. Methane, Bell points out, is 20 times more potent as a greenhouse gas than carbon dioxide.

"Fracking has been held up by numerous jurisdictions north and south of the border as a clean alternative to coal, and especially the tar sands," he says. "It's not." - Wendy Glauser, Toronto, Ont.

CMAJ 2014. DOI:10.1503/cmaj.109-4725 